\title{
Human TGFalpha-derived peptide TGFalphaL3 fused with superantigen for immunotherapy of EGFR-expressing tumours
}

\author{
Quanbin $\mathrm{Xu}^{1 *}$, Xiaojuan Zhang ${ }^{2}$, Junjie Yue ${ }^{1}$, Chuanxuan Liu'1 Cheng Cao ${ }^{1}$, Hui Zhong ${ }^{1}$, Qingjun Ma ${ }^{1 *}$
}

\begin{abstract}
Background: Monoclonal antibodies have been employed as targeting molecules of superantigen for the preclinical treatment of a variety of tumours. However, other targeting molecules, such as tumour-related ligands or peptides, are less exploited. Here, we tested other targeting molecules by genetically fusing the third loop of transforming growth factor alpha (TGFalphaL3) to mutant staphylococcal enterotoxin A (SEA D227A).

Results: The resultant fusion proteins were expressed in E. coli and purified to homogeneity through a Ni-NTA affinity column. Fusion protein TGFalphaL3SEA $2227 \mathrm{~A}$ can promote splenocyte proliferation to a level comparable to recombinant SEA (rSEA) and bind to EGFR-expressing tumour cells in an EGFR-dependent way. Consistent with these observations, TGFalphaL3SEA 227 A exerted an inhibitory effect on the growth of EGFR-expressing tumour cells both in vitro and in vivo. Notably, significant infiltrations of $\mathrm{CD}^{+}$and $\mathrm{CD}^{+} \mathrm{T}$ cells were detected in the tumour tissues of these C57BL/6 mice treated with TGFalphaL3SEA D227A, suggesting the involvement of T cells in this tumour-inhibitory process.
\end{abstract}

Conclusions: The data here showed that TGF $\alpha \mathrm{L} 3$ is capable of targeting superantigen to tumours and exerting an inhibitory effect on tumour growth, which enables TGFaL3SEA 2227 to be an attractive candidate for the immunotherapy of EGFR-expressing tumours.

\section{Background}

Superantigens (SAgs) are microbial proteins with the capacity to activate a large fraction of $\mathrm{T}$ cells [1]. The cellular receptors for SAgs are major histocompatibility complex (MHC) class II molecules and T-cell antigen receptors (TCR) [2-4]. SAgs can bind to the TCR $\beta$ subunit and activate $\mathrm{T}$ cells independently of their CD4 or CD8 phenotype when presented by MHC class II molecules $[5,6]$. Activated T cells secrete a variety of cytokines, such as TNF $\alpha$, INF $\gamma$, IL-1, IL-2, IL-6, IL-8 and IL-12 $[7,8]$. Staphylococcal enterotoxin type A (SEA) is a protein exotoxin secreted by certain strains of Staphylococcus aureus, which was demonstrated to direct cytotoxic $\mathrm{T}$ cells (CTLs) against MHC class II expressing tumour cells effectively [9]. However, MHC class II positive tumours only represent a minor fraction of the most frequent human tumours. To

\footnotetext{
* Correspondence: xuquanbin73@yahoo.com; maqingjun@sina.com ${ }^{1}$ Beijing Institute of Biotechnology, Taiping Road 27, Beijing, PR China Full list of author information is available at the end of the article
}

introduce a novel binding specificity in SEA, a monoclonal antibody (mAb) specific for colon carcinoma antigen $\mathrm{C} 215$ was initially conjugated to SEA, and the resultant conjugate Fab-SEA could lyse antigen expressing tumour cells significantly in vitro [10]. To date, SEA fused to various $\mathrm{mAb}$ have been subjected to preclinical treatment of many tumour types, some of which have finished phase I or phase II clinical trials, such as C242Fab-SEA (PNU-214565) and 5T4FabV13SEAD227A (ABR-214936)[11-14].

EGFRs are over-expressed in a variety of human tumour cells, including breast, head, neck, gastric, colorectal, oesophageal, prostate, bladder, renal, pancreatic, ovarian and nonsmall cell lung cancer (NSCLC) [15]. Moreover, the degree of EGFR over-expression is associated with an advanced tumour stage and resistance to standard therapies [16-19]. EGFR-targeted therapies have been proven to be successful by using monoclonal antibodies (i.e. Herceptin) or tyrosine kinase inhibitors (i.e. gefitinib). Unfortunately, not all patients bearing
C Biomed Central

() 2010 Xu et al; licensee BioMed Central Ltd. This is an Open Access article distributed under the terms of the Creative Commons Attribution License (http://creativecommons.org/licenses/by/2.0), which permits unrestricted use, distribution, and reproduction in any medium, provided the original work is properly cited. 
tumours with over-expression of EGFR or Her2 respond to those drugs. Only about $10 \%$ of NSCLC patients responded clinically to gefitinib; somatic mutations within the EGFR kinase domain were exclusively observed in lung cancer cells in these patients [20,21].

Human transforming growth factor alpha (hTGF $\alpha$ ) is a native ligand co-overexpressed with its receptor EGFR in many human tumours [15]. hTGF $\alpha$ consists of three loops, the third of which (TGF $\alpha$ L3) retains binding ability to EGFR but lacks mitogenic activity [22]. Binding of TGF $\alpha$ L3 to EGFR is not affected by mutations in the EGFR kinase domain, which suggests a function for TGF $\alpha$ L3 as a targeting molecule, where ligand/receptor induced internalisation is not required. Moreover, compared to mAbs, TGF $\alpha$ L3 is presumably less antigenic, thereby maintaining a longer circulating half-life. These properties enable TGF $\alpha$ L3 to be an attractive targeting molecule for the superantigens, which function only when presented on the cell surface. However, the binding ability of TGF $\alpha$ L3 to its receptor is relatively weaker than that of mAbs to antigen. This raises the question whether the affinity of a small peptide is strong enough to bring SAgs to tumours in vivo. Here, we tested this idea by fusing TGF $\alpha$ L3 to SEA (D227A), a mutant of SEA defective for MHC-II [23]. Encouragingly, we found that the resultant fusion protein TGF 2 L3$\mathrm{SEA}_{\mathrm{D} 227 \mathrm{~A}}$ could bind to EGFR-expressing tumour cells and exhibited an apparent growth inhibitory effect on the tumour cells, both in vitro and in vivo. T cells likely mediated the inhibitory effect, which was suggested by the significant infiltration of $\mathrm{CD}^{+}$and $\mathrm{CD}^{+} \mathrm{T}$ cells in fusion protein-treated tumour tissues.

\section{Results}

\section{Construction and expression of fusion proteins}

To test the effect of TGF $\alpha$ L3 fusion on SEA (D227A) activity, two sets of constructs, pET-22b-TGF $\alpha$ L3SEA $_{\mathrm{D} 227 \mathrm{~A}}$ and pET-22b-SEA ${ }_{\mathrm{D} 227 \mathrm{~A}}$ TGF $\alpha \mathrm{L} 3$, were made. These vectors are $\mathrm{pET}$-22b (+)-derived bacterial expression vectors, which drive the expression of fusion protein TGF $\alpha$ L3SEA ${ }_{\mathrm{D} 227 \mathrm{~A}}$, or SEA $\mathrm{D} 227 \mathrm{~A}_{\mathrm{A}}$ TGF $\alpha \mathrm{L} 3$, respectively (Figure 1A). Constructs were transformed into E. coli strain BL21 (DE3) and protein expression was induced by $0.5 \mathrm{mM}$ IPTG. Proteins of interest with the expected molecular weight $(30 \mathrm{kDa})$ were observed in total cell pellets (Figure 1B, lane 2, 3). About 55\% soluble fusion proteins appeared in the spheroplast when bacteria cells were induced at $22^{\circ} \mathrm{C}$ (data not shown). Soluble fusion proteins were purified from the supernatant of sonicated bacterial pellets through a Ni-NTA affinity column. Purified proteins were further dialysed against PBS and concentrated by ultrafiltration. Coomassie blue staining after SDSPAGE separation showed that both TGF $\alpha$ L3SEA ${ }_{\mathrm{D} 227 \mathrm{~A}}$ and
A

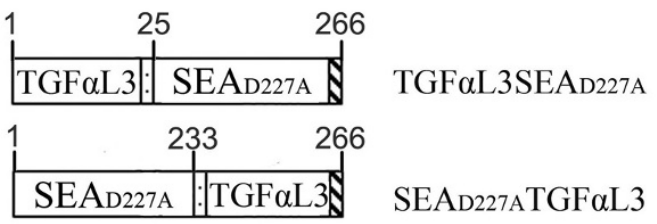

B

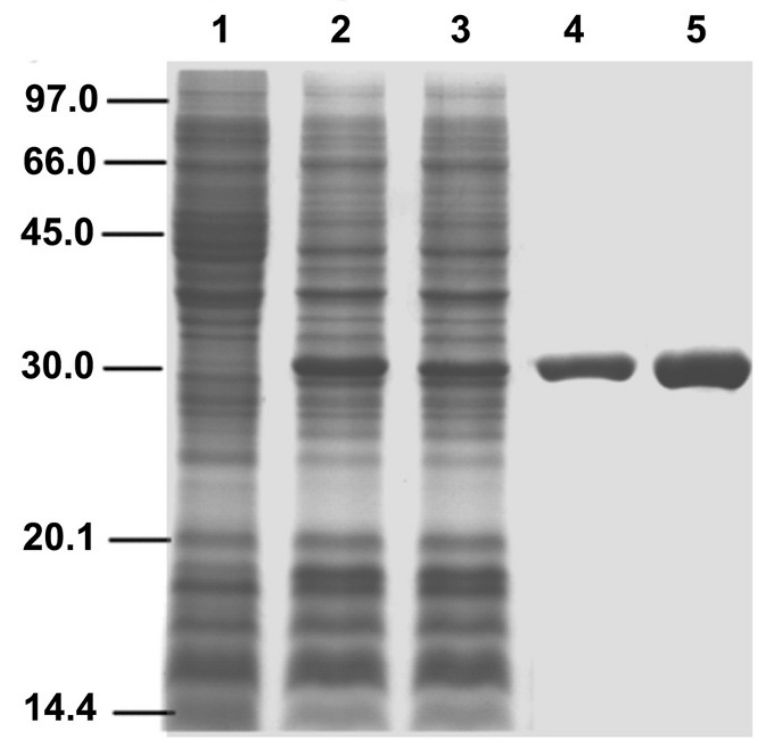

Figure 1 Expression and purification of fusion proteins (A) Schematic presentation of fusion proteins. TGF $\alpha$ L3 was fused to the $\mathrm{N}$-terminal or the $\mathrm{C}$-terminal of $\mathrm{SEAD}_{227 \mathrm{~A}}$ with 8 an eight-amino acids linker. The linker sequence (GGSGSGGG) was indicated by a dotted rectangle. All fusion proteins were tagged with a six histidinesix-histidine tag at the C-terminal; TGF $\alpha$ L3, the third loop of

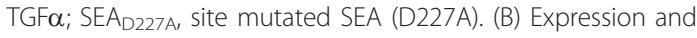
purification of fusion proteins. E. coli BL21 (DE3) cells were transformed with plasmids encoding fusion proteins, and then induced with $0.5 \mathrm{mM} \mathrm{IPTG}$ at $22^{\circ} \mathrm{C}$ overnight. The proteins were separated by a 15\% SDS-PAGE gel and stained with Coomassie blue. Lane 1, total cell proteins (TCP) of BL21 (DE3) with pET-22b (+); lane 2, TCP of BL21 (DE3) with PET-22b-TGF $\alpha$ L3SEA 227 ; lane 3, TCP of BL21 (DE3) with pET-22b-SEA $2227 \mathrm{TGF} \alpha \mathrm{L3}$; lane 4, purified TGF $\alpha$ L3SEA 2 227A; lane 5, purified SEA 2 227ATGF $\alpha$ L3.

$\mathrm{SEA}_{\mathrm{D} 227 \mathrm{~A}} \mathrm{TGF} \alpha \mathrm{L} 3$ were purified to $95 \%$ homogeneity (Figure 1B, lane 4,5).

\section{TGF $\alpha$ L3SEA $A_{\text {D227A }}$ promotes splenocyte proliferation and} binds to the EGFR

To determine the proliferating effect of fusion proteins, mice splenocytes were incubated with TGF $\alpha$ L3SEA ${ }_{\mathrm{D} 227 \mathrm{~A}}$ or $\mathrm{SEA}_{\mathrm{D} 227 \mathrm{~A}} \mathrm{TGF} \alpha \mathrm{L3}, \mathrm{rSEA}$, or $\mathrm{PHA}$ at $37^{\circ} \mathrm{C}$ for 72 hours. As showed in Figure 2A, TGF 2 L3SEA $A_{D 227 A}$ maintained $77.8 \%$ of the proliferative activity of rSEA. As a control, rSEA and PHA induced strong 


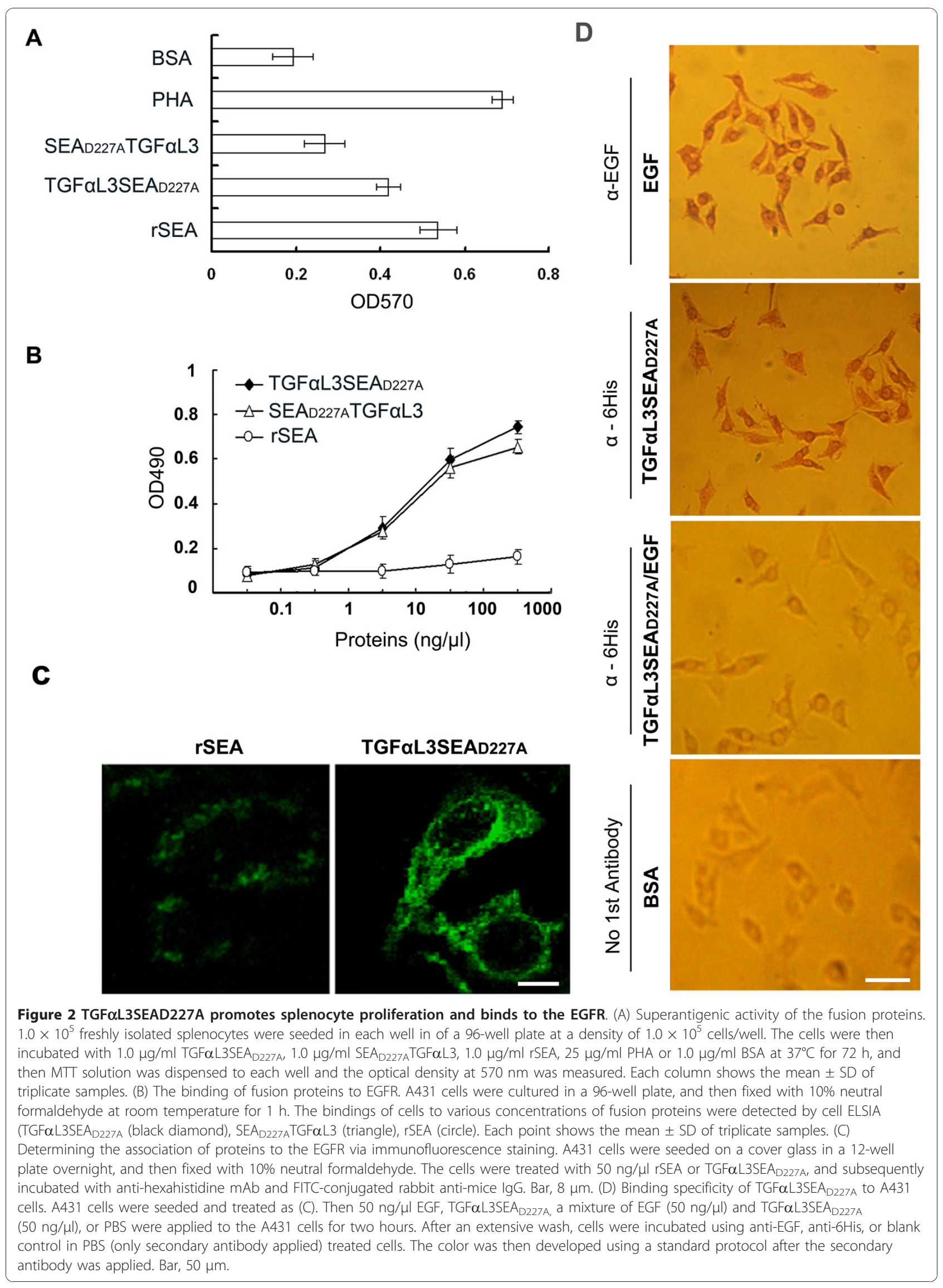


proliferation of splenocytes. However, SEA ${ }_{\mathrm{D} 227 \mathrm{~A}} \mathrm{TGF} \alpha \mathrm{L} 3$ showed only $49.8 \%$ of the proliferative activity of rSEA, implying that the TGF $\alpha$ L3 C-terminal fusion negatively affects $\mathrm{SEA}_{\mathrm{D} 227 \mathrm{~A}}$ 's activity.

To investigate whether fusion proteins efficiently bind to EGFR, A431 cells that were derived from a human epidermoid carcinoma characterised by high levels of EGFR expression, were incubated with different concentrations of 6His-tagged TGF $\alpha$ L3SEA ${ }_{\mathrm{D} 227 \mathrm{~A}}$ or SEAD227A TGF $\alpha$ L3, or rSEA (from $0.1 \mathrm{ng} / \mu \mathrm{l}$ to $1 \mathrm{ug} / \mu \mathrm{l}$ ). The cells were then incubated with anti-6His tag antibody followed by HRP conjugated anti-mouse IgG. The results showed that both TGF $\alpha$ L3SEA ${ }_{\mathrm{D} 227 \mathrm{~A}}$ and SEA $_{\text {D227A }}$ TGF $\alpha$ L3 bind to A431 cells with a similar affinity. As a control, rSEA did not bind to A431 cells (Figure 2B). Similar results were also obtained through immunostaining of recombinant proteins via anti-6His antibody. TGF $\alpha$ L3SEA $A_{\mathrm{D} 227 \mathrm{~A}}$ predominantly localised to the cell surface, as seen by fluorescent staining (Figure 2C). Unexpectedly, there was some punctate staining in the cytoplasm, which seems inconsistent with the previous report that TGF $\alpha$ L3 is not mitogenic [22]. There are two possible explanations: first, the fusion protein could be imported into cells via an unknown mechanism; second, it is artificial staining caused by fixation or nonspecific binding.

Although both TGF $\alpha$ L3SEA $_{\mathrm{D} 227 \mathrm{~A}}$ and SEA $\mathrm{D}_{227 \mathrm{~A}}$ TGF $\alpha$ L3 bind to EGFR more efficiently than rSEA, we still cannot rule out the possibility that the binding of the fusion protein to EGFR-expressing cells may not be mediated by EGFR but by other membrane proteins. To exclude this possibility, we conducted a ligand competition assay. As showed in Figure 2D, the binding of the fusion protein to A431 cells can be efficiently blocked by the addition of EGF, which binds exclusively to EGFR. This result strongly suggests that the binding of the fusion protein to A431 cells is mediated by its specific interaction with EGFR.

\section{TGF $\alpha$ L3SEA $A_{\mathrm{D} 227 \mathrm{~A}}$ inhibited tumour cell growth in vitro}

Because TGF $\alpha$ L3SEA ${ }_{\text {D227A }}$ has stronger proliferating activity than SEAD227ATGF $\alpha$ L3, we focused our interest on the activity of TGF $\alpha$ L3SEA $A_{\mathrm{D} 227 \mathrm{~A}}$. To test whether TGF $\alpha$ L3SEA $A_{D 227 A}$ bridges tumour cells and immune effecter cells together, which then leads to the lysis of tumour cells, A431 cells were initially co-cultured with increasing numbers of activated spleen cells in the presence of TGFaL3SEA ${ }_{\mathrm{D} 227 \mathrm{~A}}$. As shown in Figure 3A, half inhibition of tumour cell growth by TGF $\alpha$ L3SEA $\mathrm{D}_{227 \mathrm{~A}}$ was achieved when the effector/target $(\mathrm{E} / \mathrm{T})$ ratio was $30: 1$. Under this $\mathrm{E} / \mathrm{T}$ ratio, we found that TGF $\alpha \mathrm{L} 3-$ SEA $_{\mathrm{D} 227 \mathrm{~A}}$ inhibits A431 cell growth in a dose-dependent manner (Figure 3B). The third loop of human TGF $\alpha$ and mouse TGF $\alpha$ are highly conserved $(94 \%$ of homogeneity) (Figure 3C). Further, murine melanoma B16 cells express comparable EGFR to that found in A431 cells (Figure 3D). This evidence suggests that TGF $\alpha$ L3SEA $A_{D 227 A}$ also affects EGFR-expressing mouse tumours. Consistent with this hypothesis; the growth of B16 cells was remarkably restrained when co-incubated with TGFaL3SEA ${ }_{\text {D227A }}$ (Figure 3E).

\section{TGF $\alpha$ L3SEA $A_{D 227 A}$ inhibited tumour cell growth in vivo}

To test whether the peptide TGF $\alpha$ L3 can bring SAgs to tumours in vivo, we evaluated the anti-tumour effect of TGF $\alpha$ L3SEA $A_{\mathrm{D} 227 \mathrm{~A}}$ in mouse models. C57BL/6 mice were subcutaneously inoculated with B16 cells. When the length of tumours exceeded $5 \mathrm{~mm}$, TGF $\alpha$ L3$\mathrm{SEA}_{\mathrm{D} 227 \mathrm{~A}}$ was administrated intraperitoneally four times at one-day intervals. Tumour sizes from each mouse were recorded at the designed intervals. Consistent with the in vitro results, we found that all doses of TGF $\alpha$ L3$\mathrm{SEA}_{\mathrm{D} 227 \mathrm{~A}}$ effectively retarded tumour growth. The maximum tumour growth inhibition percentage was $84.1 \%$, which was observed in 60 pmol of TGF 2 L3SEA ${ }_{D 227 A}$ treated group at the 15th day (Figure 4A). As a control, rSEA only exerted a marginal effect on tumour growth throughout the therapeutic process (Figure 4A).

To investigate the effect of TGF L L 3SEA ${ }_{\mathrm{D} 227 \mathrm{~A}}$ on mouse survival, we treated mice with $60 \mathrm{pmol}$ of fusion drug identically when the tumours' length exceeded 1 $\mathrm{cm}$. The survival of mice was checked daily, and the percent survival of the two groups were analysed by Kaplan Meier Plot. Throughout the experiment, no deaths were observed in the TGF $\alpha$ L3SEA ${ }_{\mathrm{D} 227 \mathrm{~A}}$ group, while only $30 \%$ of the mice in the PBS control group survived (Figure 4B). This data showed that TGFaL3$\mathrm{SEA}_{\mathrm{D} 227 \mathrm{~A}}$ treatment could significantly increase the survival time for tumour-bearing mice.

\section{TGF $\alpha$ L3SEA $A_{D 227 A}$ induced immunoresponse against tumour cells}

Recruitment of antigen-specific lymphocytes to tumour tissue is a major goal in tumour immunotherapy. Both $\mathrm{CD}^{+}$and $\mathrm{CD}^{+} \mathrm{T}$ cells were targeted by colon cancer specific mAb conjugated SEA, to lyse colon cancer in vivo [10]. To investigate whether $\mathrm{TGF} \mathrm{L} 3 \mathrm{SEA}_{\mathrm{D} 227 \mathrm{~A}}$ inhibited tumour growth in a similar way, we examined for infiltration of $\mathrm{CD}^{+}$and $\mathrm{CD}^{+} \mathrm{T}$ cells in fusion protein-treated tumour tissue. Not surprisingly, both $\mathrm{CD}^{+}$and $\mathrm{CD}^{+} \mathrm{T}$ cells were observed around the tumour tissues (Figure 5AC), while recruitment of the same subtype of $\mathrm{T}$ cells was almost non-existent in the PBS control group (Figure $5 \mathrm{BD})$. These results indicated that the tumour inhibitory effect induced by TGF $\alpha$ L3SEA $A_{D 227 A}$ was, at least partially, attributed to the infiltration of both $\mathrm{CD} 4^{+}$ and $\mathrm{CD}^{+} \mathrm{T}$ cells. 


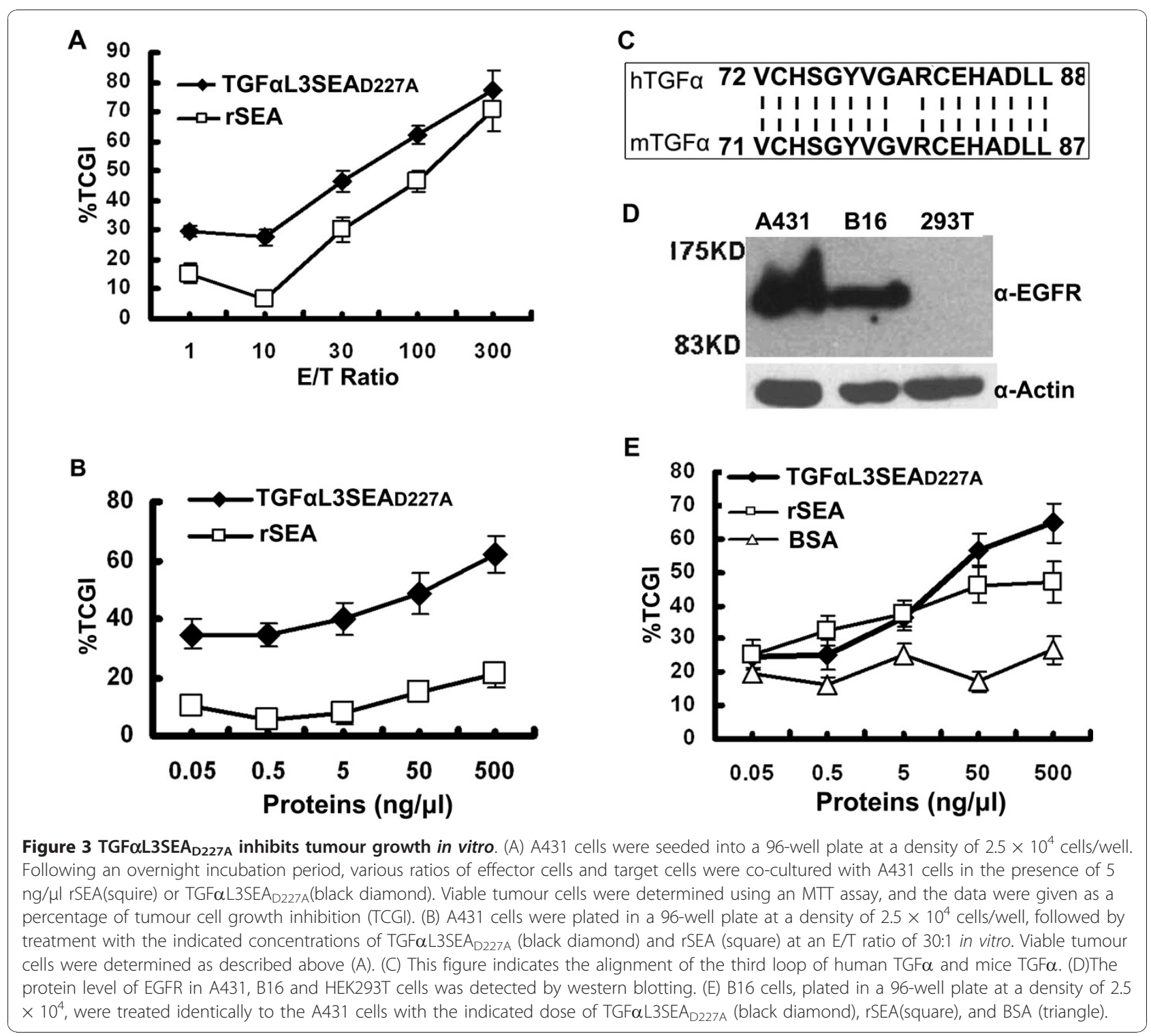

\section{Discussion}

The application of SAgs for tumour therapy has been attempted for decades. The core aim of these applications is to specifically bring SAgs to tumour cells via various strategies, including tumour specific monoclonal antibody targeted or membrane anchored SAgs $[10,24,25]$. To date, mAb targeted superantigens have been successfully applied to several types of tumours, including B lymphocytic leukaemia, neuroblastoma, non-small cell lung cancer, melanoma, and renal cell carcinoma [13,26-29]. Two of them are on the way to clinical phase trials, including C242Fab-SEA (phase I) [14] and 5T4FabV13SEAD227A (phase II) [13]. Notably, human anti-mouse antibody (HAMA) responses were observed in these trials, which cause a reduced circulating half-life, thereby limiting their further use [30].
Therefore, SAgs targeting molecules with low antigenicity were suggested for the design of the next generation of SAgs drugs [13].

Tumour-related ligand is less antigenic than mAbs, and the conjugate composed of ligand and superantigen was presumed to kill one type of tumour [31]. However, native ligands are used less in targeting SAgs to tumours. This is largely due to internalisation induced by the ligand/receptor interaction, which prevents SAgs from being presented to the surface of tumour cells and activate $\mathrm{T}$ cells. To avoid the internalisation triggered by the binding of ligand to receptor, we use a mitogenic defective TGF $\alpha 3 \mathrm{~L}$, instead of full length TGF $\alpha$, as a targeting molecule for $\mathrm{SEA}_{\mathrm{D} 227 \mathrm{~A}}$. Nevertheless, the affinity of TGFa3L with EGFR is weaker than that of full length $\mathrm{TGF} \alpha$, which raised a concern for its ability to bring 


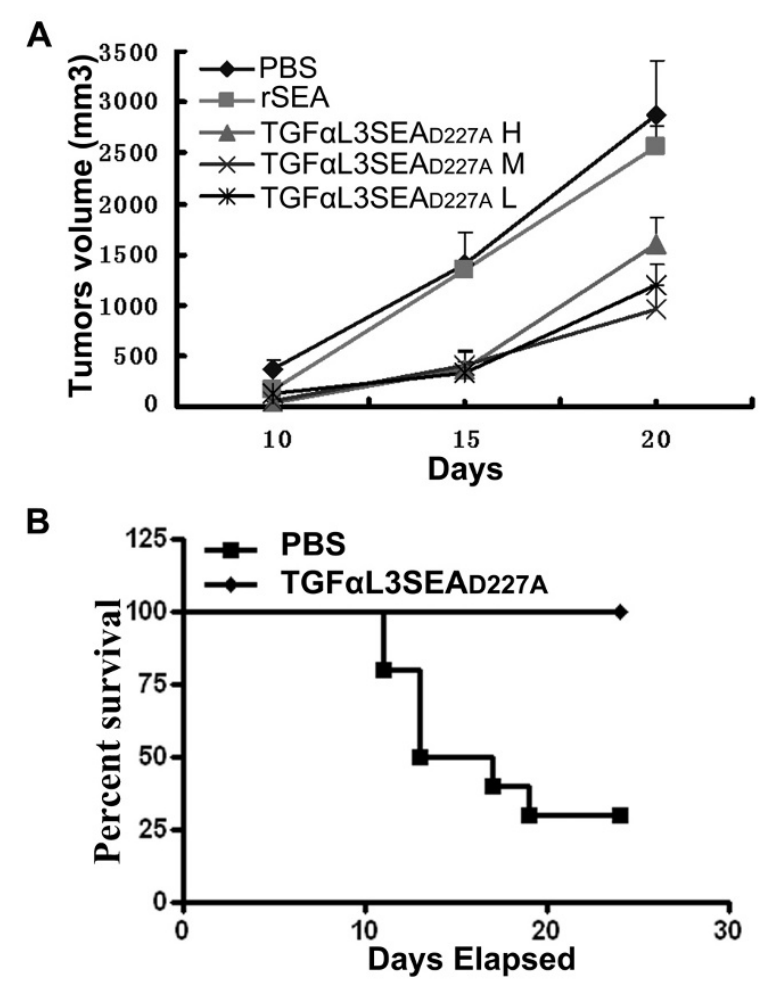

Figure 4 TGF $\alpha L_{3 S E A}{ }_{D 227 A}$ inhibits tumour growth in vivo (A) Thirty C57BL/6 mice were inoculated subcutaneously with $1.0 \times$ $10^{6}$ B16 melanoma cells. When the tumour length exceeded $0.5 \mathrm{~cm}$, the mice were separated into equal-size groups and injected intraperitoneally with $6 \mathrm{pmol}$ (asterisk), 60 pmol (multiplication), 600 pmol TGF $\alpha$ L3SEA 227 A (black triangle), 60 pmol rSEA(black square) or PBS (black diamond), respectively, four times at one day intervals. The tumour sizes were measured with callipers at the time points indicated. The tumour volumes were calculated as (length $x$ width $\left.{ }^{2}\right) / 2$. Each point shows the mean \pm SD of the tumour volume from ten treated mice. (B) Twenty mice were inoculated with $1.0 \times$ $10^{6}$ B16 melanoma cells each and then randomised into two groups. The mice were treated with 60 pmol TGF $\alpha$ L3SEA 227 A (black diamond) or PBS (black square) according to the protocol above when the tumour length exceeded $1 \mathrm{~cm}$. The survival percentages were analysed by Kaplan Meier Plot.

superantigen to the tumour in vivo. As shown in this paper, TGF $\alpha$ L3SEA ${ }_{\mathrm{D} 227 \mathrm{~A}}$ can inhibit tumour growth in a EGFR-dependent way, implying that the affinity of TGF $\alpha$ L3 is sufficient for targeting the superantigen to the tumour. Meanwhile, we also noticed a decreased therapeutic effect of the fusion protein when a higher dose of fusion protein $(600 \mathrm{pmol})$ was applied. This indicates that high dose treatment may result in increased nonspecific binding which eventually counteracts the tumour inhibitory effect of the fusion protein. The affinity of TGF $\alpha$ L3 to tumour should be further improved for better targeting efficiency. Despite that, the therapeutic effect of TGF 2 L3SEA ${ }_{\mathrm{D} 227 \mathrm{~A}}$ is still

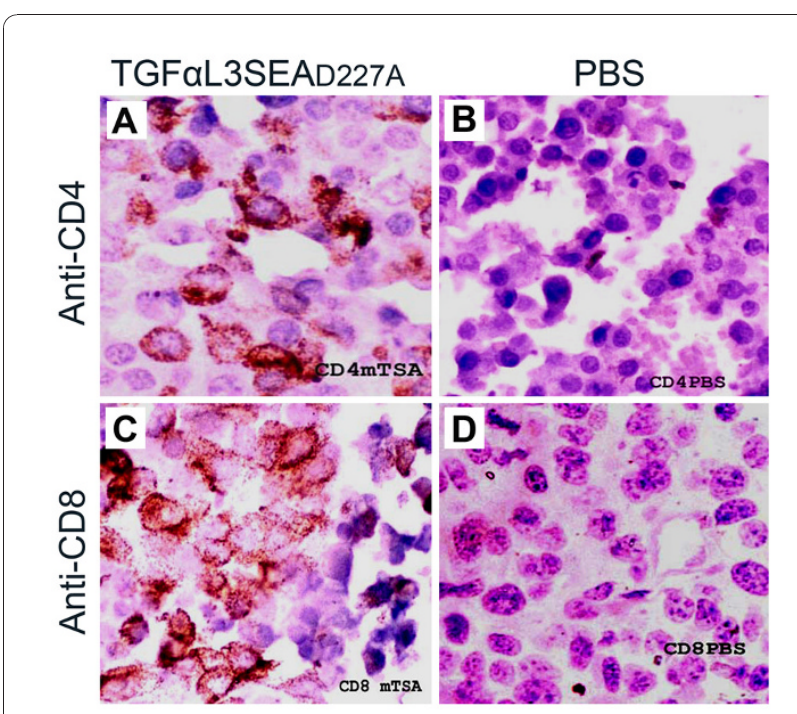

Figure 5 TGF $\alpha$ L3SEA $A_{D 227 A}$ recruits $T$ cells to the tumour tissue Tumour tissues were excised from mice treated with 60 pmol TGF $\alpha$ L3SEA 227 A or PBS after 24 days. The histochemical samples were prepared in a standard way, followed by staining with antibodies against the CD4 molecule (A and B) or the CD8 molecule (C and D). CD4 ${ }^{+}$and $C D 8^{+} T$ cells in the PBS control group were shown in figure $5 B$ and $5 \mathrm{D}$, respectively; $C D 4^{+}$and $\mathrm{CD}^{+} \mathrm{T}$ cells in the TGF $\alpha \mathrm{L} 3 \mathrm{SE} \mathrm{A}_{\mathrm{D} 227 \mathrm{~A}}$ group are shown in figure $5 \mathrm{~A}$ and $5 C$, respectively.

encouraging, especially when the dose was limited to concentrations between $6 \mathrm{pmol}$ and $60 \mathrm{pmol}$.

The antigenicity of TGF $\alpha$ LSSEA $_{\mathrm{D} 227 \mathrm{~A}}$ is presumably lower than its monoclonal antibody orthologs. To test this hypothesis, the surviving mice in the TGFaL3$\mathrm{SEA}_{\mathrm{D} 227 \mathrm{~A}}$ treated group (at day 24 in the survival ratio test) were bled before being sacrificed and ELISA was used to detect antibodies against proteins of interest. No detectable titre was found in either high and low doses of TGF $\alpha$ L3SEA ${ }_{\mathrm{D} 227 \mathrm{~A}}$-treated groups (data not shown). This result showed that the injection procedure for fusion protein in this paper could not induce apparent antibodies against these two proteins. However, we are not sure whether the same result will occur in the case of injection with a higher dose of fusion protein. It was reported that SAgs, including SEA and SEB, could act as an adjuvant to enhance humoral immunity via activating antigen specific $\mathrm{CD}^{+} \mathrm{T}$ cells [32]. This observation raises the possibility that a higher dose of TGF $\alpha$ L3$\mathrm{SEA}_{\mathrm{D} 227 \mathrm{~A}}$ may boot the antibody against itself, owing to the adjuvant effect of SEA. To this end, we increased the injection dose to $1 \mathrm{mg}$ and extended the interval between injections to two weeks. After three intramuscular injections, the titres of antibody against the proteins of interest were determined. As shown in Figure $6 \mathrm{~A}$, considerable titres of antibodies against both TGF 2 LSEA ${ }_{\mathrm{D} 227 \mathrm{~A}}$ and rSEA were observed. 


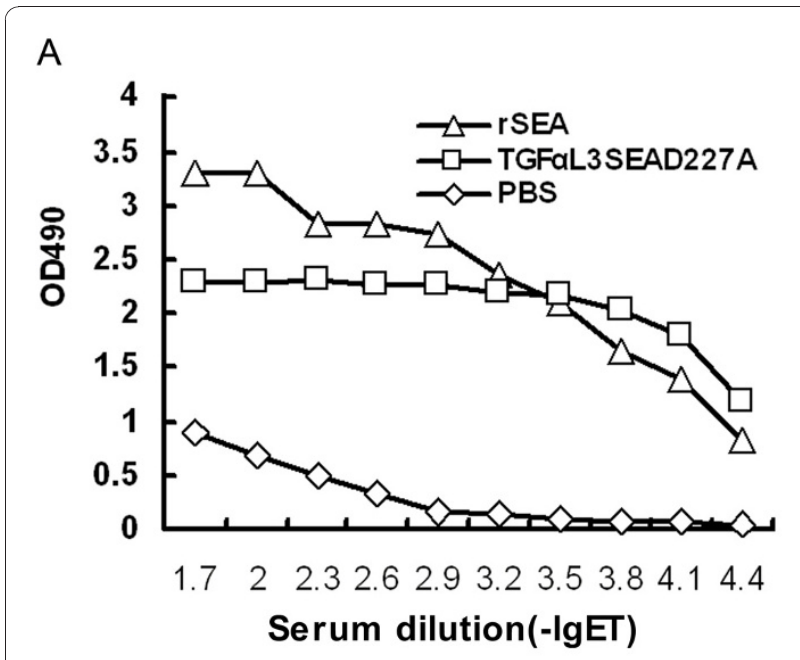

B

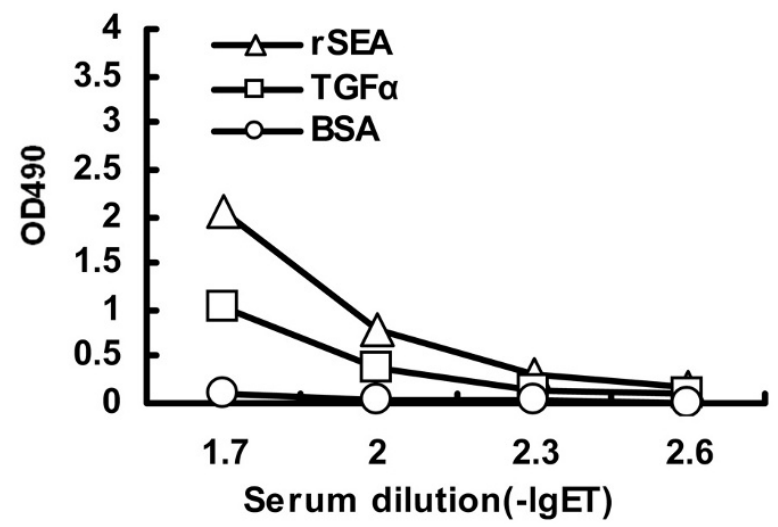

Figure 6 The antigenicity evaluation of TGF $\alpha$ L3SEA $227 A$. Nine mice were randomised into three groups and injected intramuscularly with $1 \mathrm{mg}$ TGF $\alpha$ L3SEA $227 \mathrm{~A}$, rSEA, or PBS,

respectively. The injections were repeated three times at two-week intervals. Then serum from each group was collected and analysed as follows. (A) To detect the antigenicity of TGF $\alpha$ L3SEA D227A (square) or rSEA (triangle), the corresponding proteins were coated on ELISA plates. The titres of antibody were detected in the standard way. (B) To analyse the antigen epitopes recognised by the TGF $\alpha$ L3SEA 227 A antibody, the native ligand TGF $\alpha$ (square), rSEA (triangle), or BSA(circle)was coated and the anti-serum of TGF $\alpha$ L3SEA D227A was analysed in the same way as (A).

Furthermore, the antibody against TGF $\alpha$ L3SEA ${ }_{\mathrm{D} 227 \mathrm{~A}}$ can also recognise TGFaL3 (Figure 6B). These observations confirmed the adjuvant property of SEA, indicating the inevitable antigenicity of superantigen macromolecules. Therefore, to reduce the antigenicity of SAgs macromolecules, the optimisation of both drug dose and treatment procedure will be very important when a preclinical trial is designed. Recently, it was reported that combinational use of Fab-SAgs fusion proteins with docetaxel not only improved the antitumour efficiency of Fab-SAgs but also reduced the production of anti-SEA antibody [33,34]. This finding provides another strategy to eliminate the antigenicity of SAgs macromolecules.

\section{Conclusions}

The results in this paper showed that human TGF $\alpha-$ derived TGF $\alpha$ L3 is capable of directing SAgs to tumours and exerting an inhibitory effect on tumour growth, which makes TGF $\alpha$ L3SEA $A_{\mathrm{D} 227 \mathrm{~A}}$ an attractive candidate for immunotherapy on EGFR-expressing tumours.

\section{Methods}

Bacterial strains and Cell culture

Escherichia coli strain DH5 $\alpha$ was used for plasmid propagation and cloning. Strain BL21 (DE3) (Novagen, Madison, WI, USA) was used as a host for the production of fusion proteins. A431 (epidermoid carcinoma) and B16 (a murine melanoma cell line) cells were maintained in Dulbecco's Modified Eagle medium (DMEM) (Gibco BRL, Life Technology, Rockville, MD) supplemented with $10 \%$ foetal bovine serum (FBS) (Gibco BRL, Life Technology, Rockville, MD), $2 \mathrm{mM} \mathrm{L-gluta-}$ mine, 100 units $/ \mathrm{ml}$ penicillin and $100 \mathrm{mg} / \mathrm{ml}$ streptomycin. Mouse spleen cells, freshly separated from healthy C57BL/6 mice, were grown in DMEM/F12 cell culture medium.

\section{Plasmid Construction}

A site mutation (D227A) in the SEA gene was introduced by PCR-amplification. This mutation resulted in the defective binding of SEA to the MHC-II molecule [23]. To avoid potential conformational perturbation caused by the fusion, an eight-amino acid flexible linker

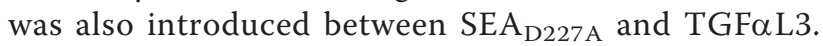
The primers for the PCR reaction include Primer 1, 5'AA GGA TCC GGT GGT GGT AGC GAG AAA AGC-3', and Primer 2, 5'-ATG AAT TCA CTC GAG ACT TGT ATA TAA ATA TAT AGC AAT ATG CAT-3'. The PCR product was purified and digested with BamH I and Xho I. The digested SEA $\mathrm{D}_{\mathrm{D} 227 \mathrm{~A}}$ gene was inserted into the pET-22b (+) vector (Novagen, Madison, WI, USA) to produce the plasmid pET$\mathrm{SEA}_{\mathrm{D} 227 \mathrm{~A}}$. To fuse TGF $\alpha \mathrm{L} 3$ to the $\mathrm{N}$ terminal of $\mathrm{SEA}_{\mathrm{D} 227 \mathrm{~A}}$, Primers 3 and 4 were annealed and extended (Primer 3: 5'-AA CAT ATG GTA TGC CAC TCT GGT TAC GTT GGC GCA CGT TGT GAA CAC-3'; Primer 4: 5'-TT GGA TCC AGA ACC ACC GAG CAG GTC AGC GTG TTC ACA ACG TGC GCC -3'). The resultant products were then digested by Nde I and BamH I and ligated into pET-22b-SEA $A_{D 227 A}$ cut with the same restriction enzymes. The resultant recombinant vector was termed $\mathrm{pET}-22 \mathrm{~b}-\mathrm{TGF} \alpha \mathrm{L} 3 \mathrm{SEA}_{\mathrm{D} 227 \mathrm{~A}}$, and encodes TGF $\alpha$ L3 and $\mathrm{SEA}_{\mathrm{D} 227 \mathrm{~A}}$, plus an 
eight-amino acid linker (GGSGSGGG) between them (Figure 1A).

To evaluate the influence of the TGF $\alpha$ L3 fusion direction on protein activity, another plasmid pET-22b-SEAD227A TGF $\alpha$ L3 was also generated, in which the TGF $\alpha$ L3 coding sequence was induced to the 3 '-terminal of the SEA gene. First, a Sac I site was introduced into the 3'-terminal of the SEA gene by PCR using Primer 1 and Primer 5 (Primer 5: 5'-AA GTG GTG GAG CTC GAC ACT TGT A-3') and the PCR product was cloned into pET-22b, resulting in plasmid pET-22b-SEA ${ }_{D 227 A} S a c I$. Then the cDNA encoding TG $\alpha$ L3 plus the eight-linker was generated by annealing and extending Primers 6 and 7 (Primer 6: 5' -AA GAG CTC GGT GGT GGT TCT GGT GGT GGT TCT GTA TGC CAC TCT GGT TAC GTT GGC-3'; Primer 7: 5'-AA CTC GAG GAG CAG GTC AGC GTG TTC GCA ACG TGC GCC AAC GTA ACC AGA GTG GCA -3'). The extension product and $\mathrm{pET}-22 \mathrm{~b}-\mathrm{SEA}_{\mathrm{D} 227 \mathrm{~A}} \mathrm{SacI}$ were doubly digested by Sac I and Xho I and then ligated together. The resultant vector was named $\mathrm{pET}-22 \mathrm{~b}-\mathrm{SEA}_{\mathrm{D} 227 \mathrm{~A}}$ TGF $\alpha$ L3 (Figure 1A). All DNA constructs were confirmed by DNA sequencing. Both constructs were expected to express fusion proteins with 266 amino acids (aa), including TGF $\alpha$ L3 (17 aa), mutated SEA (233 aa), linker sequence ( 8 aa), C-terminal histidine tag (6 aa), and two amino acids (LE) before the histidine tag encoded by the restriction enzyme recognising sequence for cloning.

\section{Expression and purification of fusion proteins}

Construct pET-22b-TGF $\alpha$ L3SEA ${ }_{\mathrm{D} 227 \mathrm{~A}}$ or pET-22b-SEAD227A TGF $\alpha$ L3 was transformed into BL21 (DE3) and then induced with $0.5 \mathrm{mM}$ IPTG at $22^{\circ} \mathrm{C}$ overnight. The cell pellet was washed and suspended in binding buffer (0.5 mol/l NaCl, $0.1 \mathrm{~mol} / \mathrm{l}$ Tris.Cl, pH8.0), followed by a regular sonication procedure. The cell debris was removed by centrifugation at $12,000 \mathrm{~g}$ for $30 \mathrm{~min}$. The supernatant was then applied to Ni-charged chelatingSepharose (Pharmacia Biotech, Uppsala, Sweden). After being washed with binding buffer plus $80 \mathrm{mM}$ imidazole, the fusion protein was eluted with the binding buffer containing $250 \mathrm{mM}$ imidazole and then dialysed against PBS buffer overnight. Fusion proteins were enriched by ultrafiltration and quantified by BCA assay (Pierce, Rockford, USA).

\section{Splenocyte proliferation assay}

Splenocytes freshly isolated from the spleen of healthy C57BL/6 mice were seeded into 96-well plates at a density of $1 \times 10^{5}$ cells per well in the presence of $1.0 \mu \mathrm{g} / \mathrm{ml}$ TGF $\alpha$ LSSEA $_{\mathrm{D} 227 \mathrm{~A}}, 1.0 \mu \mathrm{g} / \mathrm{ml} \mathrm{SEA}_{\mathrm{D} 227 \mathrm{~A}}$ TGF $\alpha \mathrm{L} 3,1.0 \mu \mathrm{g} / \mathrm{ml} \mathrm{rSEA}, 25 \mu \mathrm{g} / \mathrm{ml}$ phytohemagglutinin (PHA) or $1.0 \mu \mathrm{g} / \mathrm{ml}$ BSA. The treated cells were cultured at $37^{\circ} \mathrm{C}$ for $72 \mathrm{~h}$, then $20 \mu \mathrm{l} 5 \mathrm{mg} / \mathrm{ml} \mathrm{3-(4,5-}$ dimethylthiazol-2- $\mu \mathrm{l})-2$, 5- diphenyltetrazolium bromide (MTT) was added for another $4 \mathrm{~h}$. Finally, $150 \mu \mathrm{l}$ dimethyl sulphoxide (DMSO) was dispensed into each well and the optical density at $570 \mathrm{~nm}$ was measured on an ELISA reader (Biorad 550). The relative proliferating activity of the fusion protein was given by $\% 100 \times$ OD570 of the fusion protein/OD570 of the rSEA.

\section{Cell ELISA assay}

Binding of TGF $\alpha$ L3SEA $A_{\mathrm{D} 227 \mathrm{~A}}$ or SEA $\mathrm{D}_{\mathrm{D} 27 \mathrm{~A}} \mathrm{TGF} \alpha \mathrm{L} 3$ to EGFR was detected by cell ELISA [35]. Briefly, $1 \times 10^{4}$ A431 cells per well were partitioned into 96 -well flatbottomed plates overnight, then fixed with $10 \%$ neutral formaldehyde $(10 \mathrm{mmol} / \mathrm{l} \mathrm{PBS,} \mathrm{10 \%} \mathrm{formaldehyde,}$ $\mathrm{pH7.4)}$ at room temperature for $1 \mathrm{~h}$. The cells were blocked with $5 \mathrm{mg} / \mathrm{mL}$ bovine serum albumin (BSA) for $2 \mathrm{~h}$ and incubated with different concentrations of TGF $\alpha$ L3SEA ${ }_{\mathrm{D} 227 \mathrm{~A}}, \mathrm{SEA}_{\mathrm{D} 227 \mathrm{~A}} \mathrm{TGF} \alpha \mathrm{L} 3$ or rSEA at $37^{\circ} \mathrm{C}$ for $1 \mathrm{~h}$. After being washed five times with PBST (10 $\mathrm{mmol} / \mathrm{l}$ PBS pH7.4, 0.05\% Tween-20), the cells were incubated with anti-hexahistidine MAb (1:1250), followed by HRP-conjugated rabbit anti-mice IgG (1:5000) and washed as previously. Finally, the colour was developed by $0.4 \mathrm{mg} / \mathrm{ml}$ orthopenylenediamine (OPD) solution with $1.5 \% \mathrm{H}_{2} \mathrm{O}_{2}$, and the absorbance at $490 \mathrm{~nm}$ was analysed on ELISA reader.

\section{In vitro Tumour cell growth inhibition assay}

Tests were performed according to the previously described method [36]. B16 cells or A431 cells in DMEM medium were added at a density of $2.5 \times 10^{4}$ cells/well to 96-well flat-bottomed plates, followed by treatment with the indicated reagents and effector cells to a total volume of $100 \mu \mathrm{l}$. Cells were cultured for $72 \mathrm{~h}$ at $37^{\circ} \mathrm{C}$ in $5 \% \mathrm{CO} 2$. The remaining viable tumour cells were determined using the MTT assay. The data were given as the percentage of tumour cell growth inhibition (\% TCGI), which was calculated as the following: \%TCGI $=100 \times\left(A_{\text {test }}-A_{b}\right) /\left(A_{c}-A_{b}\right) . A_{\text {test }}$ is the absorbance of tumour cells grown in the presence of the effector cells and various reagents, $A_{c}$ is the absorbance of the tumour cells grown in the medium, and $A_{b}$ is the absorbance of the medium only.

\section{In vivo tumour inhibition assay}

C57BL/6 mice (4-6 weeks old) were obtained and maintained at the certified animal facility of Beijing Institute of Biotechnology. Fifty mice were inoculated subcutaneously with $1.0 \times 10^{6}$ B16 cells suspended in PBS plus $1 \%$ C57BL/ 6 mouse serum. When the tumour length exceeded $0.5 \mathrm{~cm}$, the mice were randomly divided into five groups (10 mice per group) and subsequently injected intraperitoneally with $6 \mathrm{pmol}(\mathrm{L}), 60 \mathrm{pmol}(\mathrm{M})$, 
600 pmol (H) TGF $\alpha$ L3SEA ${ }_{\mathrm{D} 227 \mathrm{~A}}, 60$ pmol rSEA or PBS four times at one day intervals. Tumour size was measured with calipers at the time points indicated. The tumour volume was calculated as (length $\times$ width $\left.^{2}\right) / 2$ [37]. The tumour growth inhibition ratio was calculated as $\% 100 \times$ (tumour volume of PBS control-tumour volume of interest)/tumour volume of PBS. The survival percentages of mice were analysed by Kaplan Meier Plot. All animal experiments were designed and conducted according to the recommendations of the Beijing Experimental Animal Regulation Board (SYXK/JING/ 2005/0031).

\section{Western blotting and Immunohistochemical analysis}

Western blot analysis was performed routinely with the EGFR monoclonal antibody (Santa Cruz Biotechnology, Inc) or anti- $\beta$ actin polyclonal antibody (Santa Cruz Biotechnology, Inc). For immunohistochemical analysis, the tumour tissues from sacrificed mice were embedded in paraffin after being fixed with $10 \%$ formaldehyde in PBS (pH7.4). The sections were stained with mouse antiCD4 (1:500) or anti-CD8 mAbs (1:400) (Millipore, Upstate, MA, USA) at $4^{\circ} \mathrm{C}$ overnight, followed by biotinylated secondary antibody (1:5000) for $10 \mathrm{~min}$ at room temperature. Finally, the colour was developed in a standard way.

\section{Acknowledgements}

This work was supported by the National Natural Science Foundation of China $(3030041,30971444)$ to QX.

\section{Author details}

'Beijing Institute of Biotechnology, Taiping Road 27, Beijing, PR China.

${ }^{2}$ Institute of Genetics and Developmental Biology, No.1 West Beichen Road, Chinese Academy of Sciences, Beijing, PR China.

\section{Authors' contributions}

QX designed and performed experiments, analysis and manuscript writing. XZ conducted partial experiments and drafted the manuscript. JY collaborated on the design of the protein linker. CC provided partial reagents and suggestions in preparation for this manuscript. CL, QM, and $\mathrm{HZ}$ supervised the whole process. All authors have read and approved the final manuscript.

Received: 6 May 2010 Accepted: 22 December 2010

Published: 22 December 2010

\section{References}

1. Marrack P, Kappler J: The staphylococcal enterotoxins and their relatives. Science 1990, 248:705-711.

2. White J, Herman A, Pullen AM, Kubo R, Kappler JW, Marrack P: V Betaspecific superantigen staphylococcal enterotoxin B: stimulation of mature T cells and clonal detection in neonatal mice. Cell 1989, 56:27-35.

3. Dellabona P, Peccoud J, Kappler J, Marrack P, Benoist C, Mathis D: Superantigens interact with MHC class II molecules outside of the antigen groove. Cell 1990, 62:1115-1121.

4. Irwin MJ, Hudson KR, Fraser JD, Gascoigne NR: Enterotoxin residues determining T cell receptor $\mathrm{V} \beta$ binding specificity. Nature 1992, 359:841-843.
5. Herman A, Kappler JW, Marrack P, Pullen AM: Superantigens: mechanism of T-cell stimulation and role in immune responses. Annu Rev Immunol 1991, 9:745-772.

6. Norton SD, Schlievert PM, Novick RP, Jenkins MK: Molecular requirements for T cell activation by the staphylococcal toxic shock syndrome toxin-1. $\mathrm{J}$ Immunol 1990, 144(6):2089-2095.

7. Cavaillon JM, Muller-Alouf H, Alouf JE: Cytokines in streptococcal infections. An opening lecture. Adv Exp Med Biol 1997, 418:869-879.

8. Litton MJ, Sander B, Murphy E, O'Garra A, Abrams JS: Early expression of cytokines in lymph nodes after treatment in vivo with Staphylococcus enterotoxin B. J Immunol Methods 1994, 175(1):47-58.

9. Dohlsten M, Lando PA, Hedlund G, Trowsdale J, Kalland T: Targeting of human cytotoxic T lymphocytes to MHC class Il-expressing cells by staphylococcal enterotoxins. Immunology 1990, 71(1):96-100.

10. Dohlsten M, Hedlund G, Akerblom E, Lando PA, Kalland T: Monoclonal antibody-targeted superantigens: a different class of anti-tumour agents. Proc Natl Acad Sci USA 1991, 88(20):9287-9291.

11. Nielsen SE, Zeuthen J, Lund B, Persson B, Alenfall J, Hansen HH: Phase I study of single, escalating doses of a superantigen-antibody fusion protein (PNU-214565) in patients with advanced colorectal or pancreatic carcinoma. J Immunother 2000, 23(1):146-153.

12. Giantonio BJ, Alpaugh RK, Schultz J, McAleer C, Newton DW, Shannon B, Guedez Y, Kotb M, Vitek L, Persson R, Gunnarsson PO, Kalland T, Dohlsten M, Persson P, Weiner LM: Superantigen-based immunotherapy: a phase I trial of PNU-214565, a monoclonal antibody-staphylococcal enterotoxin A recombinant fusion protein, in advanced pancreatic and colorectal cancer. J Clin Oncol 1997, 15(5):1994-2007.

13. Shaw DM, Connolly NB, Patel PM, Kilany S, Hedlund G, Nordle O, Forsberg G, Zweit J, Stern PL, Hawkins RE: A phase II study of a 5T4 oncofoetal antigen tumour-targeted superantigen (ABR-214936) therapy in patients with advanced renal cell carcinoma. Br J Cancer 2007, 96(4):567-574.

14. Alpaugh RK, Schultz J, McAleer C, Giantonio BJ, Persson R, Burnite M, Nielsen SE, Vitek L, Persson B, Weiner LM: Superantigen-targeted therapy: phase I escalating repeat dose trial of the fusion protein PNU-214565 in patients with advanced gastrointestinal malignancies. Clin Cancer Res 1998, 4(8):1903-1914.

15. Salomon DS, Brandt R, Ciardiello F, Normanno N: Epidermal growth factorrelated peptides and their receptors in human malignancies. Crit Rev Oncol Hematol 1995, 19:183-232.

16. Yarden $Y$, Sliwkowski MX: Untangling the ErbB signalling network. Nat ReV Mol Cell Biol 2001, 2(2):127-137.

17. Chen $X$, Yeung TK, Wang Z: Enhanced drug resistance in cells coexpressing ErbB2 with EGF receptor or ErbB3. Biochem Biophys Res Commun 2000, 277(3):757-763.

18. Sartor $\mathrm{Cl}$ : Biological modifiers as potential radiosensitizers: targeting the epidermal growth factor receptor family. Semin Oncol 2000, 27(6 Suppl 11):15-20, discussion 92-100.

19. Newby JC, Johnston SR, Smith IE, Dowsett M: Expression of epidermal growth factor receptor and c-erbB2 during the development of tamoxifen resistance in human breast cancer. Clin Cancer Res 1997, 3(9):1643-1651.

20. Fukuoka M, Yano S, Giaccone G, Tamura T, Nakagawa K, Douillard JY, Nishiwaki Y, Vansteenkiste J, Kudoh S, Rischin D, Eek R, Horai T, Noda K, Takata I, Smit E, Averbuch S, Macleod A, Feyereislova A, Dong RP, Baselga J: Multi-institutional randomized phase II trial of gefitinib for previously treated patients with advanced non-small-cell lung cancer (The IDEAL 1 Trial) [corrected]. J Clin Oncol 2003, 21(12):2237-2246.

21. Paez JG, Janne PA, Lee JC, Tracy S, Greulich H, Gabriel S, Herman P, Kaye FJ, Lindeman N, Boggon TJ, Naoki K, Sasaki H, Fujii Y, Eck MJ, Sellers WR, Johnson BE, Meyerson M: EGFR mutations in lung cancer: correlation with clinical response to gefitinib therapy. Science 2004, 304(5676):1497-1500.

22. Nestor JJ Jr, Newman SR, DeLustro B, Todaro GJ, Schreiber AB: A synthetic fragment of rat transforming growth factor alpha with receptor binding and antigenic properties. Biochem Biophys Res Commun 1985, 129(1):226-232.

23. Holzer U, Orlikowsky T, Zehrer C, Bethge W, Dohlsten M, Kalland T, Niethammer D, Dannecker GE: T-cell stimulation and cytokine release induced by staphylococcal enterotoxin A (SEA) and the SEAD227A mutant. Immunology 1997, 90(1):74-80. 
24. Wang Q, Yu H, Ju DW, He L, Pan JP, Xia DJ, Zhang LH, Cao X: Intratumoural IL-18 gene transfer improves therapeutic efficacy of antibody-targeted superantigen in established murine melanoma. Gene Ther 2001, 8(7):542-550.

25. Xiu F, Cai Z, Yang Y, Wang X, Wang J, Cao X: Surface anchorage of superantigen SEA promotes induction of specific antitumour immune response by tumour-derived exosomes. J Mol Med 2007, 85(5):511-521.

26. Gidlof C, Dohlsten M, Lando P, Kalland T, Sundstrom C, Totterman TH: A superantigen-antibody fusion protein for T-cell immunotherapy of human B-lineage malignancies. Blood 1997, 89(6):2089-2097.

27. Holzer U, Bethge W, Krull F, Ihle J, Handgretinger R, Reisfeld RA, Dohlsten M, Kalland T, Niethammer D, Dannecker GE: Superantigenstaphylococcal-enterotoxin-A-dependent and antibody-targeted lysis of GD2-positive neuroblastoma cells. Cancer Immunol Immunother 1995, 41(2):129-136.

28. Tordsson JM, Ohlsson LG, Abrahmsen LB, Karlstrom PJ, Lando PA, Brodin TN: Phage-selected primate antibodies fused to superantigens for immunotherapy of malignant melanoma. Cancer Immunol Immunother 2000, 48(12):691-702.

29. Langer CJ, Katherine AR, Robert F, Weiner LM, Schiller J, Kopreski M Andre R, Goran F: Phase II study of anatumomab mafenatox (ABR214936) in Advanced NSCLC: Results of a multi-institutinal open label repeat dose trial with patient-specific dose escalation. Lung Cancer 2003, 41:46s.

30. Penichet $\mathrm{ML}$, Morrison SL: Design and engineering human forms of monoclonal antibodies. Drug Dev Res 2004, 61:121-136.

31. Wang L, Zhang H, Zhang S, Yu M, Yang X: Construction and characterization of a novel superantigen fusion protein: bFGF/SEB. Cancer Invest 2009, 27: 376-383.

32. Torres BA, Perrin GQ, Mujtaba MG, Subramaniam PS, Anderson AK, Johnson HM: Superantigen enhancement of specific immunity: antibody production and signaling pathways. J Immunol 2002, 169(6):2907-2914

33. Sundstedt A, Celander M, Hedlund G: Combining tumour-targeted superantigens with interferon-alpha results in synergistic anti-tumour effects. Int Immunopharmacol 2008, 8(3):442-452.

34. Sundstedt A, Celander M, Ohman MW, Forsberg G, Hedlund G: Immunotherapy with tumour-targeted superantigens (TTS) in combination with docetaxel results in synergistic anti-tumour effects. Int Immunopharmacol 2009, 9(9):1063-1070

35. Lorenzo DC, Nigro A, Piccoli R, D’Alessio G: A new RNase-based immunoconjugate selectively cytotoxic for ErbB2-over-expressing cells. FEBS Letters 2002, 516:208-212.

36. Dohlsten $M$, Lando PA, Bjork $P$, Abrahmsen L, Ohlsson L, Lind P, Kalland T: Immunotherapy of human colon cancer by antibody-targeted superantigens. Cancer Immunol Immunother 1995, 41:162-168.

37. Tsai SC, Gansbacher B, Tait L, Miller FR, Heppner GH: Induction of antitumour immunity by interleukin- 2 gene-transduced mouse mammary tumour cells versus transduced mammary stromal fibroblasts. J Natl Cancer Inst 1993, 85:546-553.

doi:10.1186/1472-6750-10-91

Cite this article as: Xu et al.: Human TGFalpha-derived peptide

TGFalphaL3 fused with superantigen for immunotherapy of EGFRexpressing tumours. BMC Biotechnology 2010 10:91.

\section{Submit your next manuscript to BioMed Central and take full advantage of:}

- Convenient online submission

- Thorough peer review

- No space constraints or color figure charges

- Immediate publication on acceptance

- Inclusion in PubMed, CAS, Scopus and Google Scholar

- Research which is freely available for redistribution

Submit your manuscript at www.biomedcentral.com/submit
Ciomed Central 